\title{
Does Monetary Policy Affect Economic Growth in Jordan? Evidence from Ordinary Least Square Models
}

\author{
Mohamed Ibrahim Mugableh ${ }^{1}$ \\ ${ }^{1}$ Head Department of Financial and Banking Sciences, College of Administrative and Financial Sciences, Irbid \\ National University, Jordan \\ Correspondence: Mohamed Ibrahim Mugableh, Head Department of Financial and Banking Sciences, College of \\ Administrative and Financial Sciences, Irbid National University, P.O Box: 2600-Zip Code: 21110, Jordan.
}

Received: October 30, 2018

Accepted: November 26, $2018 \quad$ Online Published: December 6, 2018

doi:10.5539/ibr.v12n1p27

URL: https://doi.org/10.5539/ibr.v12n1p27

\begin{abstract}
The main objective of this paper is to analyze equilibrium and dynamic causality relationships between monetary policy tools and economic growth in Jordan for the period (1990-2017). For this purpose, it considers the autoregressive distributed lag (ARDL) and vector error correction (VEC) models estimations. The results of ARDL approach show that monetary policy variables (i.e., real interest rate and money supply) have positive impact on economic growth in long-run and short-run except inflation rate. In addition, the results of VECM indicate bidirectional causal relationships between economic growth and monetary policy variables in long-run and short-run.
\end{abstract}

Keywords: econometrics, Jordan, macroeconomics, monetary

\section{Introduction}

The aim of this paper is to examine equilibrium and dynamic causality relationships between monetary policy instruments and economic growth in Jordan. However, Jordan is an upper middle income developing kingdom with a population of 9.904 million (World Bank, 2018). Appendices A, B, C, and D show that economic growth rate (gross domestic product (GDP)), real interest rate (IR), money supply (M2), and inflation rate (IFR) registered an annual growth rate of $5 \%, 8.5 \%, 9.6 \%$, and $-2 \%$, respectively. Recently, the government of Jordan has implemented Jordan economic growth plan 2018-2022 to stabilize the macroeconomic indicators. This will be achieved through a 5\% growth rate (USD 1.8 billion of growth per year) in top five contributors sectors to GDP which are finance, government services, transport, manufacturing, and tourism \& hospitality (Jordan Economic Growth Plan Report 2018-2022, 2018).

Different studies examined the impact of monetary policy tools on economic growth. The results of some studies confirmed that there is no impact of monetary policy on economic growth (see for example Kamaan, 2014; Monteil et al., 2012; Lashkary \& Kashani, 2011; Buigut, 2009). On the other hand, the findings of other studies confirmed that monetary policy is vital for economic growth (i.e., Havi \& Enu, 2014; Fasanya et al., 2013; Kareem et al., 2013; Vinayagathasan, 2013; Chaudhry et al., 2012; Coibion, 2011; Amarasekara, 2009; Suleiman et al., 2009; Ali et al., 2008; Rafiq \& Mallick, 2008; Khabo \& Harmse, 2005).

The efficiency of monetary policy is a key of an energetic financial system. The larger the financial system, the more sensitive interest rate will be in production and cumulative demand. Thus, economic growth stability is based on monetary policy instruments (i.e., IR, M2, and IFR). The leading contribution of this study differs from other studies in Jordan (see for example Obeid \& Awad, 2017; Soufan, 2013). That is, in this study, effects of the monetary policy on economic growth are investigated using vector error correction (VEC) and autoregressive distributed lag (ARDL) models. In addition, the hypotheses of equilibrium (long-run and short-run) relationships and dynamic causality analysis between monetary policy variables (i.e., IR, M2, and IFR) and economic growth are examined. In this study, after the introduction, data and empirical model are presented. Following methodology and results estimates, conclusions and policy recommendations are explained.

\section{Data and Empirical Model}

This paper analyses the equilibrium and dynamic causality relationships between economic growth and monetary policy instruments in Jordan, particularly interest rate, money supply and level of inflation. Due to the 
availability of data, the range of the analysis will be annual time-series data for the (1990-2017) period, establishing a small sample size of 28 observations. The GDP in local currency unit (i.e., Billions JD) is used to measure economic growth in Jordan.

Interest rate (IR) is a major monetary policy instrument and measured by real interest rate. The money supply is measured by the broad monetary aggregate (M2, Billions JD) as a proxy of the total monetary aggregates available in the Jordan's economy. Inflation rate (IFR) refers to consumer prices (annual \%). Data used in this study is taken from the World Bank (2018). The variables are transformed into a natural logarithmic form (i.e., LogGDP, LogIR, LogM2, and LogIFR).

Following the analysis of Akapler and Duhok (2018), the empirical model is formulated as the following:

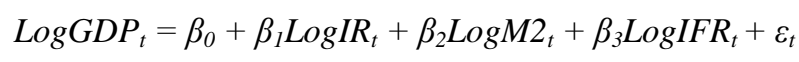

Where, $\varepsilon_{\mathrm{t}}$ is the residual term distributed with zero mean and constant variance $\left(\varepsilon_{\mathrm{t}} \sim \mathrm{N}\left(0, \sigma^{2}\right)\right)$. Based on financial and economic theories, the signs of coefficients are expected to be as follows: $\beta_{1}, \beta_{2}>0$, and $\beta_{3}<0$ (see, inter alia, Friedman, 1970; Mundell, 1963; Fisher, 1930; Keynes, 1930).

\section{Methodology and Results Estimates}

\subsection{Unit Root, Co-integration, and Equilibrium Relationships}

This paper employs the ARDL approach proposed by Pesaran et al. (2001) to examine equilibrium relationships between monetary policy variables (i.e., IR, M2, and IFR) and GDP. Before estimating the ARDL approach, it is necessary to test unit root and co-integration. Table 1 shows that the variables are stationary at the first difference (i.e., I(1)). The advantage of the ARDL approach is that it allows the nonlinear relationship among the GDP, the IR, the M2, and the IFR. The model is specified as follows:

$$
\begin{aligned}
\Delta \operatorname{LogGDP}_{\mathrm{t}}=\alpha_{0}+\alpha_{1 \mathrm{t}} \operatorname{LogGDP}_{\mathrm{t}-1}+ & \alpha_{2 \mathrm{t}} \operatorname{LogIR}_{\mathrm{t}-1}+\alpha_{3 \mathrm{t}} \operatorname{LogM}_{\mathrm{t}-1}+\alpha_{4 \mathrm{t}} \operatorname{LogIFR}_{\mathrm{t}-1} \\
& +\sum_{\mathrm{s}=1}^{\mathrm{h}} \alpha_{5 \mathrm{~s}} \Delta \operatorname{LogGDP}_{\mathrm{t}-\mathrm{s}}+\sum_{\mathrm{s}=0}^{\mathrm{h}} \alpha_{6 \mathrm{~s}} \Delta \operatorname{LogIR}_{\mathrm{t}-\mathrm{s}}+\sum_{\mathrm{s}=0}^{\mathrm{h}} \alpha_{7 \mathrm{~s}} \Delta \operatorname{LogM} 2_{\mathrm{t}-\mathrm{s}} \\
& +\sum_{\mathrm{s}=0}^{\mathrm{h}} \alpha_{8 \mathrm{~s}} \Delta \operatorname{LogIFR}_{\mathrm{t}-\mathrm{s}}+\varepsilon_{\mathrm{t}}
\end{aligned}
$$

Where $\Delta$ is a lag operator; $\alpha_{0}$ is constant; $\varepsilon_{\mathrm{t}}$ is assumed to be $\mathrm{N}\left(0, \sigma^{2}\right) ; \alpha_{1} \alpha_{2} \alpha_{3} \alpha_{4}$ are for long-run estimates, while other coefficients: $\alpha_{5} \alpha_{6} \alpha_{7} \alpha_{8}$ are for short-run estimates. For ARDL approach, the first step is to test Eq. (2) by ordinary least square. The null hypothesis of no co-integration is $\mathrm{H}_{0}: \alpha_{1}=\alpha_{2}=\alpha_{3}=\alpha_{4}=0$ against alternative $\mathrm{H}_{1}: \alpha_{1} \neq \alpha_{2} \neq \alpha_{3} \neq \alpha_{4} \neq 0$. The bounds F-statistics test is used to check the existence of co-integration among variables. Critical values for F-statistics test are given by Pesaran and Pesaran (2009). Pesaran et al. (2001) argued that if the calculated F-statistics value is higher than the upper bound, i.e., $\mathrm{I}(1)$, then, the $\mathrm{H}_{0}$ of no co-integration is rejected and concludes the existence of co-integration. If the calculated F-statistics value is below the lower bound, i.e., $\mathrm{I}(0)$, then, the $\mathrm{H}_{0}$ of no co-integration is accepted. Thus, there are no long-run relationships among variables. If the calculated F-statistics value is between $\mathrm{I}(0)$ and $\mathrm{I}(1)$, then results are unsettled.

The vector autoregressive (VAR) model is used to find lag order that was two through Akaike information criterion and Schwarz Bayesian criterion. Table 2 shows the results of co-integration test. The calculated F-statistics value (5.20) is higher than the upper bound (5.12) at 1\% significance level, showing a co-integration between economic growth and monetary policy instruments. The result of co-integration is consistent with result obtained for Nigeria (Sulaiman \& Migiro, 2014). 
Table 1. Results of Unit Root Test

\begin{tabular}{lcccc}
\hline \multirow{2}{*}{ Variable } & \multicolumn{3}{c}{ t-statistic } & \multicolumn{2}{c}{ Critical-value } \\
\cline { 2 - 5 } & -1.31 & $\mathrm{I}(1)$ & $5 \%$ & $10 \%$ \\
\hline LogGDP $_{\mathrm{t}}$ & -2.22 & $-5.10^{* *}$ & -3.52 & -3.19 \\
LogIR $_{\mathrm{t}}$ & -1.71 & $-3.25^{* * *}$ & -4.20 & \\
$\operatorname{LogM}_{\mathrm{t}}$ & -2.47 & $-3.56^{* *}$ & & \\
LogIFR $_{\mathrm{t}}$ & $-3.36^{* * *}$ & & \\
\hline Notes. (1) ${ }^{* * *, * * *}$ & represent the significance at 1\%, 5\%, and 10\% levels, respectively. (2) The analysis of unit root \\
test is conducted using Augmented Dickey-Fuller test. (3) Source: Author's estimations using E-views software \\
package 9.0.
\end{tabular}

Table 2. Results of Co-integration Test

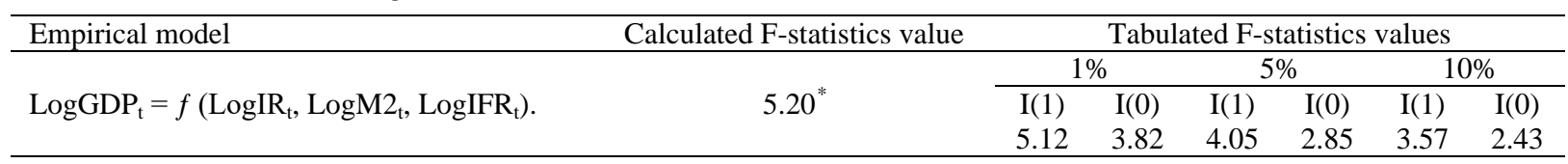

Notes. (1) The tabulated F-statistics values were retrieved from Pesaran and Pesaran (2009, Case II: intercept and no trend, p. 544). (2) * denotes the significance at $1 \%$ level. (3) The computed F-statistic value was obtained from Micro-Fit software package 5.1.

Once co-integration is well-known, the next step is to estimate equilibrium relationships between economic growth and monetary policy variables. In Table 3, the long-run and short-run results show that all variables have positive impact on economic growth except inflation rate. These results are similar to the results obtained for Vietnam (Anwar and Nguyen, 2018), Canada (Champagne and Sekkel, 2018), and Turkey (Varlik and Berument, 2017).

Table 3. ARDL Estimation Results

\begin{tabular}{lc}
\hline Variable & Coefficient \\
\hline Constant term & $-2.501(0.596)$ \\
Long-run: & $8.132^{*}(0.009)$ \\
LogIR $_{\mathrm{t}-1}$ & $7.506^{* * *}(0.015)$ \\
$\operatorname{LogM}_{\mathrm{t}-1}$ & $-3.546^{* * *}(0.053)$ \\
$\operatorname{LogIFR}_{\mathrm{t}-1}$ & \\
Short-run: & $2.126^{* *}(0.011)$ \\
$\Delta \operatorname{LogIR}$ & $3.461^{* *}(0.025)$ \\
$\Delta \operatorname{LogM} 2_{\mathrm{t}-1}$ & $-5.799^{* * *}(0.059)$ \\
$\Delta \operatorname{LogIFR}_{\mathrm{t}-1}$ & \\
\hline
\end{tabular}

Notes. (1) P-values in parentheses. (2) ${ }^{* * *, * * *}$ represent $1 \%, 5 \%$, and $10 \%$ levels of significance, respectively. (3)

Source: Author's estimations using E-views software package 9.0.

Table 4. Results of Diagnostic Tests

\begin{tabular}{llll}
\hline Diagnostic tests & Null Hypotheses $\left(\mathrm{H}_{0}\right)$ & F-statistics value & Decision \\
\hline Normality & Error terms aren't $\mathrm{N}\left(0, \sigma^{2}\right)$ & $6.52^{* *}(0.022)$ & ${\text { Reject } \mathrm{H}_{0}}^{*}$ \\
Ramsey reset & Empirical model isn't correctly specified & $4.51^{* *}(0.034)$ & Reject $\mathrm{H}_{0}$ \\
Homoscedasticity & Heteroskedasticity problem & $7.76^{*}(0.010)$ & Reject $\mathrm{H}_{0}$ \\
\hline
\end{tabular}

Notes. (1) P-values in parentheses. (2) ${ }^{*}$ and ${ }^{* *}$ represent $1 \%$ and $5 \%$ levels of significance, respectively. (3) Source:

Author's estimations using Micro-Fit software package 5.1.

Inflation is a double-edge sword, that it can be beneficial to economic growth but at the same time, it may adversary affect. Thus, it's necessary to follow the strategy of moderation to control inflation in order to have a positive effect on economic growth. The mechanisms used by central bank are money supply and interest rate. That is, money supply is the main economic engine, while interest rate is considered an important tool to motivate investors. Results of diagnostic tests in Table 4 confirm that Eq. (2) is free from heteroskedasticity problem, correctly specified, and residuals are normally distributed.

\subsection{The VECM Granger Causality}

Once co-integration is confirmed among variables, it is necessary to employ the VECM instead of VAR model. The negative and significant error correction term (Ect) shows long-run causal relationships, while the F-statistics test illustrates the short-run causality. Eq. (2) can be transformed into an error correction model: 


$$
\left[\begin{array}{l}
\Delta \text { LogGDP }_{t} \\
\Delta \text { LoglR }_{t} \\
\Delta \text { LogM2 }_{t} \\
\Delta \text { LoglFR }_{t}
\end{array}\right]=\left[\begin{array}{l}
\alpha_{1 \mathrm{t}} \\
\alpha_{2 \mathrm{t}} \\
\alpha_{3 \mathrm{t}} \\
\alpha_{4 \mathrm{t}}
\end{array}\right]+\sum_{\mathrm{s}=0}^{\mathrm{h}}\left[\begin{array}{l}
\delta_{11 \mathrm{t}} \delta_{12 \mathrm{t}} \delta_{13 \mathrm{t}} \delta_{14 \mathrm{t}} \\
\delta_{21 \mathrm{t}} \delta_{22 \mathrm{t}} \delta_{23 \mathrm{t}} \delta_{24 \mathrm{t}} \\
\delta_{31 \mathrm{t}} \delta_{32 \mathrm{t}} \delta_{33 \mathrm{t}} \delta_{34 \mathrm{t}} \\
\delta_{41 \mathrm{t}} \delta_{42 \mathrm{t}} \delta_{43 \mathrm{t}} \delta_{44 \mathrm{t}}
\end{array}\right]\left[\begin{array}{l}
\Delta \text { LogG DP } \\
\Delta \text { LoglR } \\
\Delta \text { LogM2 } \\
\Delta \text { LoglF R }
\end{array}\right]_{\mathrm{t}-\mathrm{s}}\left[\begin{array}{l}
\beta_{1 \mathrm{t}} \\
\beta_{2 \mathrm{t}} \\
\beta_{3 \mathrm{t}} \\
\beta_{4 \mathrm{t}}
\end{array}\right][\mathrm{E} \mathrm{ct}]_{\mathrm{t}-1}+\left[\begin{array}{l}
\varepsilon_{1 \mathrm{t}} \\
\varepsilon_{2 \mathrm{t}} \\
\varepsilon_{3 \mathrm{t}} \\
\varepsilon_{4 \mathrm{t}}
\end{array}\right]
$$

Where $\alpha_{i t}(\mathrm{i}=1, \ldots . .4)$ denote the intercept terms; $\delta_{\mathrm{ijt}}(\mathrm{i}, \mathrm{j}=1, \ldots \ldots 4)$ represent the coefficients to test the $\mathrm{H}_{0}$ of no Granger causality in short-run; $\beta_{\mathrm{it}}(\mathrm{i}=1, \ldots \ldots 4)$ denote the coefficients of $\left(\mathrm{Ect}_{\mathrm{t}-1}\right) \mathrm{s}$. These coefficients test the $\mathrm{H}_{0}$ of no Granger bidirectional causality in long-run. The results of VECM Granger causality analysis are given in Table 5. There are bidirectional causal relationships between economic growth and monetary policy tools in long-run and short-run. These results are same to the results obtained by Srithilat and Sun (2017) for Laos. The highly significance and negative error correction term confirms the co-integration among variables. For the first model (i.e., economic growth), the error correction term is highly significance at $1 \%$ level and register -0.80 .

Table 5. Results of VECM Granger Causality Analysis

\begin{tabular}{|c|c|c|c|c|c|}
\hline \multirow{3}{*}{ Dependent variables } & \multicolumn{5}{|c|}{ Sources of causation } \\
\hline & \multicolumn{4}{|c|}{ Short-run } & Long-run \\
\hline & $\Delta \operatorname{LogGDP}{ }_{t}$ & $\Delta \log \mathrm{IR}_{\mathrm{t}}$ & $\Delta \log M 2_{t}$ & $\Delta \operatorname{LogIFR}_{t}$ & Ect $_{\mathrm{t}-1}$ \\
\hline$\Delta \operatorname{LogGDP}_{t}$ & - & $5.75^{*}(0.01)$ & $6.65^{*}(0.01)$ & $5.3^{* * *}(0.02)$ & $-0.80^{*}(.01)$ \\
\hline$\Delta \operatorname{LogIR}_{\mathrm{t}}$ & $9.3^{*}(0.01)$ & & $7.4^{*}(0.01)$ & $5.2^{* *}(0.02)$ & $-0.70 *(.01)$ \\
\hline$\Delta \log M 2_{t}$ & $8.1^{*}(0.01)$ & $6.3^{*}(0.01)$ & - & $4.4^{* *}(0.02)$ & $-0.60 *(.01)$ \\
\hline$\Delta \log _{\mathrm{IFR}}$ & $2.3^{* *}(0.03)$ & $4.3^{* * *}(0.02)$ & $1.3^{* *}(0.04)$ & - & $-0.50 *(.01)$ \\
\hline
\end{tabular}

Notes. (1) P-values in parentheses. (2) ${ }^{*}$ and ${ }^{* *}$ represent $1 \%$ and $5 \%$ levels of significance, respectively. (3) Source: Author's estimations using E-views software package 9.0.

\section{Conclusions and Policy Recommendations}

The current paper analyzes equilibrium and dynamic causality relationships between economic growth and monetary policy variables (i.e., real interest rate, money supply, and inflation rate). It employs ARDL and VEC models over the (1990-2017) period. The results show the existence of co-integration between economic growth and monetary policy variables. While the results of ARDL approach show that monetary policy variables have positive impact on economic growth in long-run and short-run except inflation rate. In addition, the results of VECM indicate bidirectional causal relationships between economic growth and monetary policy variables in long-run and short-run. A rising from these findings, this paper recommends the following:

- The growth of the economy should be the topmost consideration when implementing monetary policy. Strong macroeconomic policies (i.e., Jordan economic growth plan 2018-2022) should be followed to stabilize the economy.

- The financial sector in Jordan should be more regulated and supervised by ministry of finance and central bank in order to achieve the efficiency of monetary policies.

\section{Acknowledgments}

This work would not have been possible without the financial support of Irbid National University, college of administrative and financial sciences, department of financial and banking sciences, Jordan.

\section{References}

Akalpler, E., \& Duhok, D. (2018). Does monetary policy affect economic growth: evidence from Malaysia. Journal of Economic and Administrative Sciences, 34(1), 2-20. https://doi.org/10.1108/JEAS-03-2017-0013

Ali, S., Irum, S., \& Ali, A. (2008). Whether fiscal stance or monetary policy is effective for economic growth in case of South Asian countries. The Pakistan Development Review, 47(4). https://doi.org/10.30541/v47i4IIpp.791-799

Amarasekara, C. (2009). The impact of monetary policy on economic growth and inflation in Sri Lanka. Central Bank of Sri Lanka Staff Studies, 38, 1-44. https://doi.org/10.4038/ss.v38i1.1220

Anwar, S., \& Nguyen, L. P. (2018). Channels of monetary policy transmission in Vietnam. Journal of Policy Modeling, 40(4), 709-729. https://doi.org/10.1016/j.jpolmod.2018.02.004

Buigut, S. (2009). Monetary policy transmission mechanism: Implications for the proposed East African Community (EAC) Monetary Union. Retrieved from 
http://www.csae.ox.ac.uk/conferences/2009-EdiA/paperlist

Champagne, J., \& Sekkel, R. (2018). Changes in monetary regimes and the identification of monetary policy shocks: narrative evidence from Canada. Journal of Monetary Economics, in press. https://doi.org/10.1016/j.jmoneco.2018.06.002

Chaudhry, I. S., Qamber, Y., \& Farooq, F. (2012). Monetary policy, inflation and economic growth in Pakistan: Exploring the co-integration and causality relationships. Pakistan Journal of Commerce and Social Science, 6(2), 332-347.

https://www.semanticscholar.org/paper/Monetary-Policy-\%2C-Inflation-and-Economic-Growth-in-Chaudhr $\mathrm{y} / 1 \mathrm{c} 96 \mathrm{ad} 72220 \mathrm{ba1014755779d9432c56db6b983 \textrm {ca }}$

Coibion, O. (2011). Are the effects of monetary policy shocks big or small? NBER Working Paper: 17034. Cambridge, M.A. https://www.jstor.org/stable/41426399

Fasanya, I. O., Onakoya, A. B. O., \& Agboluaje, M. A. (2013). Does monetary policy influence economic growth in Nigeria? Asian Economic and Financial Review, 3(5), 635-646. http://www.aessweb.com/pdf-files/635-646.pdf

Fisher, I. (1930). The Theory of Interest, the Online Library of Liberty, Liberty Fund Inc., 2005, Macmillan Company. Retrieved from http://oll.libertyfund.org/Home3/index.php

Friedman, M. (1970). A theoretical framework for monetary analysis, Journal of Political Economy, 78(2), 193-238. https://msuweb.montclair.edu/ lebelp/FriedmanMonetaryAnalysisJPE1970March.pdf

Havi, E. D. K., \& Enu, P. (2014). The effect of fiscal policy and monetary policy on Ghana's economic growth: which policy is more potent? International Journal of Empirical Finance, 3(2), 61-75. https://ideas.repec.org/a/rss/jnljef/v3i2p3.html

Jordan Economic Growth Plan Report (2018). The Jordan Economic Growth Plan 2018-2022 (JEGP), retrieved from: http://egp.jo/en, accessed on October 2018.

Kamaan, C. K. (2014). The effect of monetary policy on economic growth in Kenya. International Journal of Business and Commerce, 3(8), 11-24. https://www.ijbcnet.com/3-8/IJBC-14-3802.pdf

Kareem, R. O., Afolabi, A. J., Raheemand, K. A., \& Bashir, N. O. (2013). Analysis of Fiscal and Monetary Policies on Economic Growth: Evidence from Nigerian Democracy. Current Research Journal of Economic Theory, 5(1), 11-19. http://maxwellsci.com/print/crjet/v5-11-19.pdf

Keynes, J. M. (1930). A Treatise on Money, the Collected Writings of John Maynard Keynes. Treatise on money: the collected writings of John Maynard Keynes, 6. https://doi.org/10.1017/UPO9781139520171

Khabo, V., \& Harmse, C. (2005). The impact of monetary policy on economic growth of a small open economy: the case of South Africa. South African Journal of Economic and Management Sciences, 8(3), 348-362. https://sajems.org/index.php/sajems/article/view/1201

Lashkary, M., \& Kashani, H. B. (2011). The Impact of Monetary Variables on Economic Growth in Iran: A Monetarists' Approach. World Applied Sciences Journal, 15(3), 449-456. https://pdfs.semanticscholar.org/ec51/5675d6573c4405a5e858976275cf433b867f.pdf

Monteil, P., Adam, C., \& O’Conell, S. (2012). Financial architecture and the monetary transmission mechanism in Tanzania. CSAE Working Paper WPS, 03.

https://www.theigc.org/publication/financial-architecture-and-the-monetary-transmission-mechanism-in-tan zania

Mundell, R. (1963). Capital mobility and stabilization policy under fixed and flexible exchange rates. Canadian Journal of Economics and Political Science, 29, 475-485. https://doi.org/10.2307/139336

Obeid, R., \& Awad, B. (2017). Effectiveness of monetary policy instruments on economic growth in Jordan using vector error correction model. International Journal of Economics and Finance, 9(11), 194-206. http://www.ccsenet.org/journal/index.php/ijef/article/view/70569

Pesaran, B., \& Pesaran, M. H. (2009). Time series econometrics using micro fit 5.0. Oxford University Press, UK. https://www.amazon.com/Time-Econometrics-using-Microfit-5-0/dp/B01A65ABJI

Pesaran, M. H., Shin, Y., \& Smith, R. J. (2001). Bounds testing approaches to the analysis of level relationships. Journal of Applied Econometrics, 16(3), 289-326. https://doi.org/10.1002/jae.616

Rafiq, S. M., \& Mallick, K. S. (2008). The effect of monetary policy on output in EMU3: a sign restriction 
approach. Journal of Macroeconomics, 30(4), 1756-1791. https://doi.org/10.1016/j.jmacro.2007.12.003

Soufan, T. (2013). The causal relationship between monetary policy and economic growth in Jordan during the period 1978-2010. Interdisciplinary Journal of Contemporary Research in Business, 5(8), 56-67. https://www.zuj.edu.jo/wp-content/staff-research/economic/dr.Thikraiat-Soufan/3.pdf

Srithilat, K., \& Sun, G. (2017). The Impact of Monetary Policy on Economic Development: Evidence from Lao PDR. Global Journal of Human-Social Science, 17(2), version 1. https://ideas.repec.org/p/pra/mprapa/79369.html

Sulaiman, L. A., \& Migiro, S. O. (2014). The nexus between monetary policy and economic growth in Nigeria: a causality test. Public and Municipal Finance, 3(2), 35-40.

https://businessperspectives.org/images/pdf/applications/publishing/templates/article/assets/5868/PMF_201 4_02_Sulaiman.pdf

Suleiman, D. M., Wasti, S. K. A., Lal, I., \& Hussain, A. (2009). An empirical investigation between money supply government expenditure, output and prices: the Pakistan evidence. European Journal of Economics, Finance and Administrative Sciences, 17, 60-68.

https://www.econ-jobs.com/research/52433-An-Empirical-Investigation-between-Money-Supply-Governme nt-Expenditure-Output--Prices-The-Pakistan-Evidence.pdf

Varlik, S., \& Berument, M. H. (2017). Multiple policy interest rates and economic performance in a multiple monetary-policy-tool environment. International Review of Economics \& Finance, 52, 107-126. https://doi.org/10.1016/j.iref.2017.10.004

Vinayagathasan, T. (2013). Monetary policy and the real economy: A Structural VAR Approach for Sri Lanka. National Graduate Institute for Policy Studies, 13(13), 1-31. http://www.grips.ac.jp/r-center/en/discussion_papers/13-13/

World Bank (2018). World development indicators database. Retrieved from https://data.worldbank.org/?locations=JO-XT 
Appendix A. Time Trend of Economic Growth Rate in Jordan over the (1990-2017) period

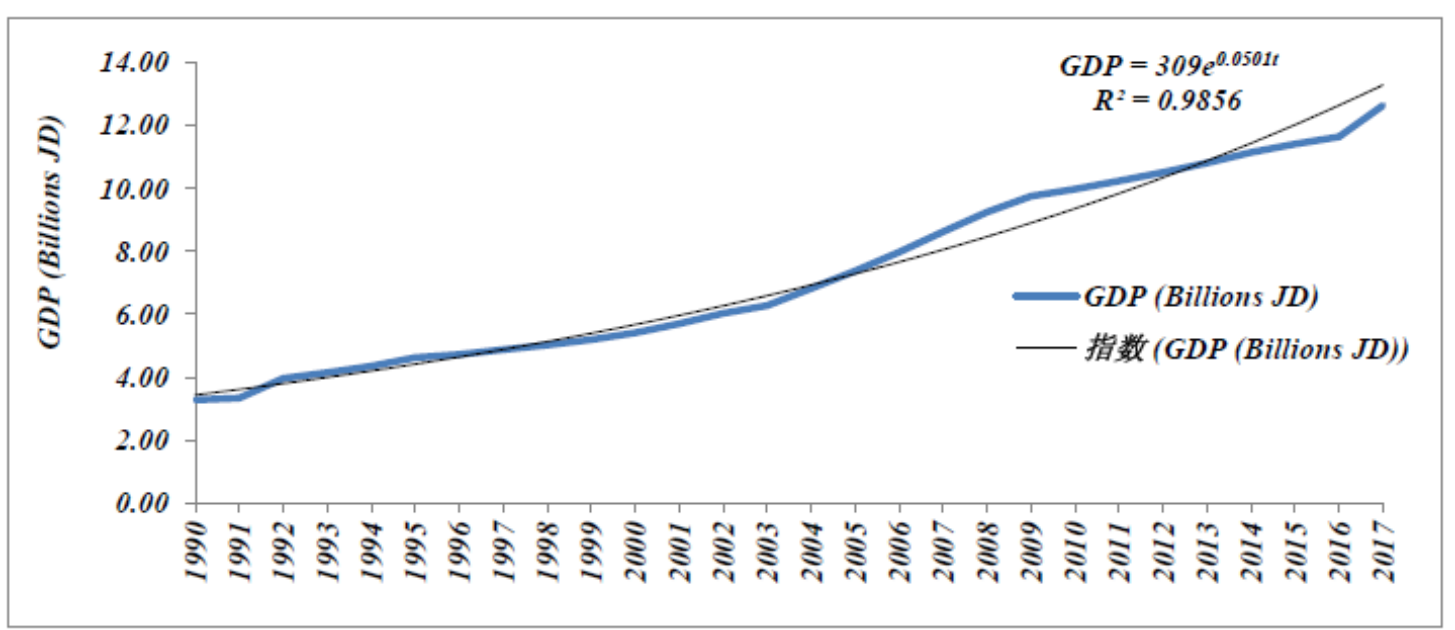

Appendix B. Time Trend of Real Interest Rate in Jordan over the (1990-2017) period

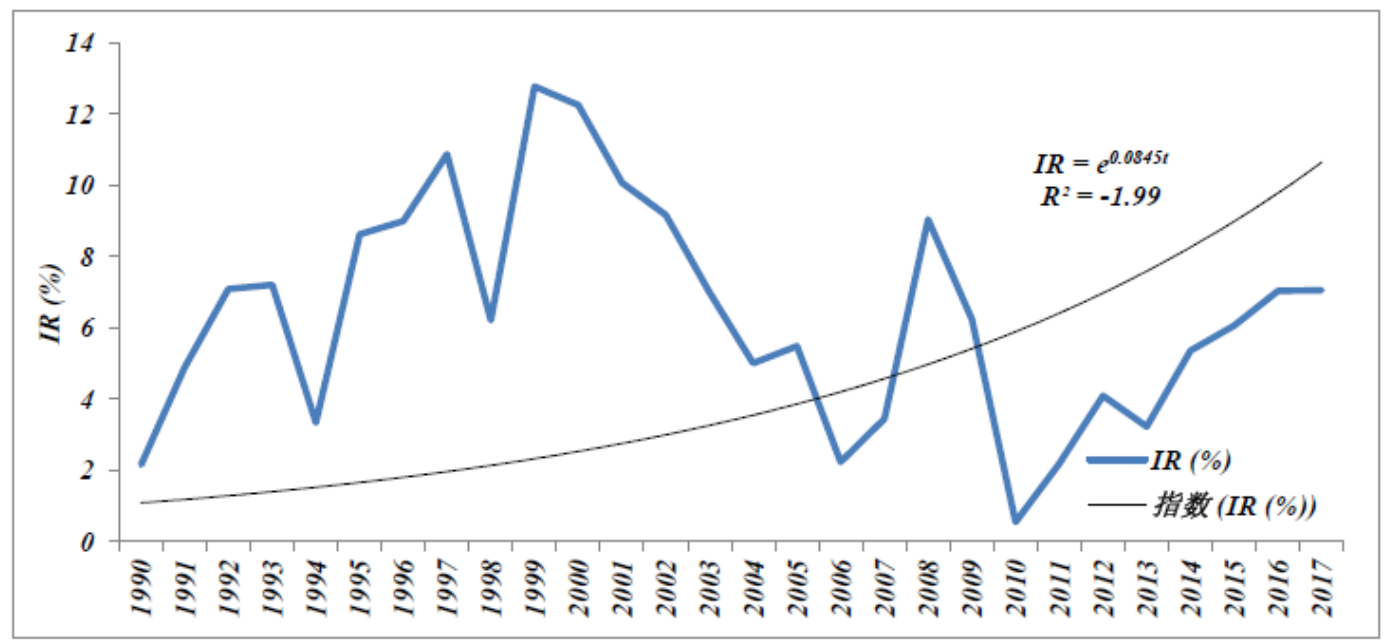

Appendix C. Time Trend of Money Supply in Jordan over the (1990-2017) period

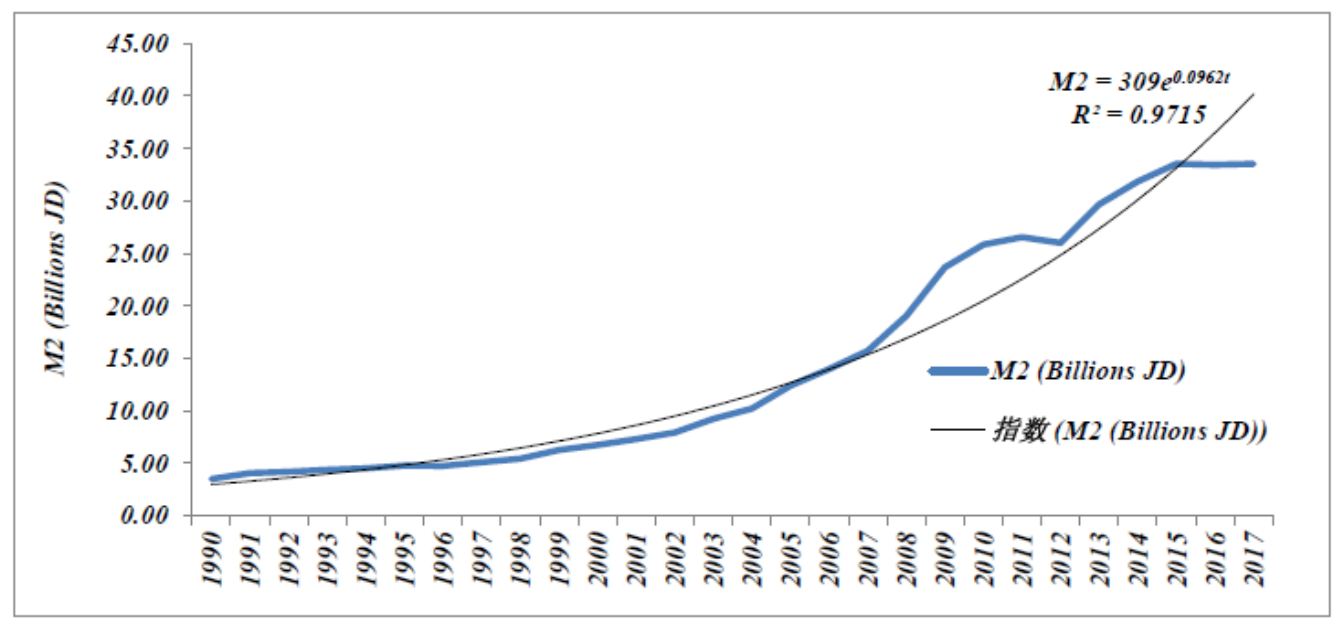


Appendix D. Time Trend of Inflation Rate in Jordan over the (1990-2017) period

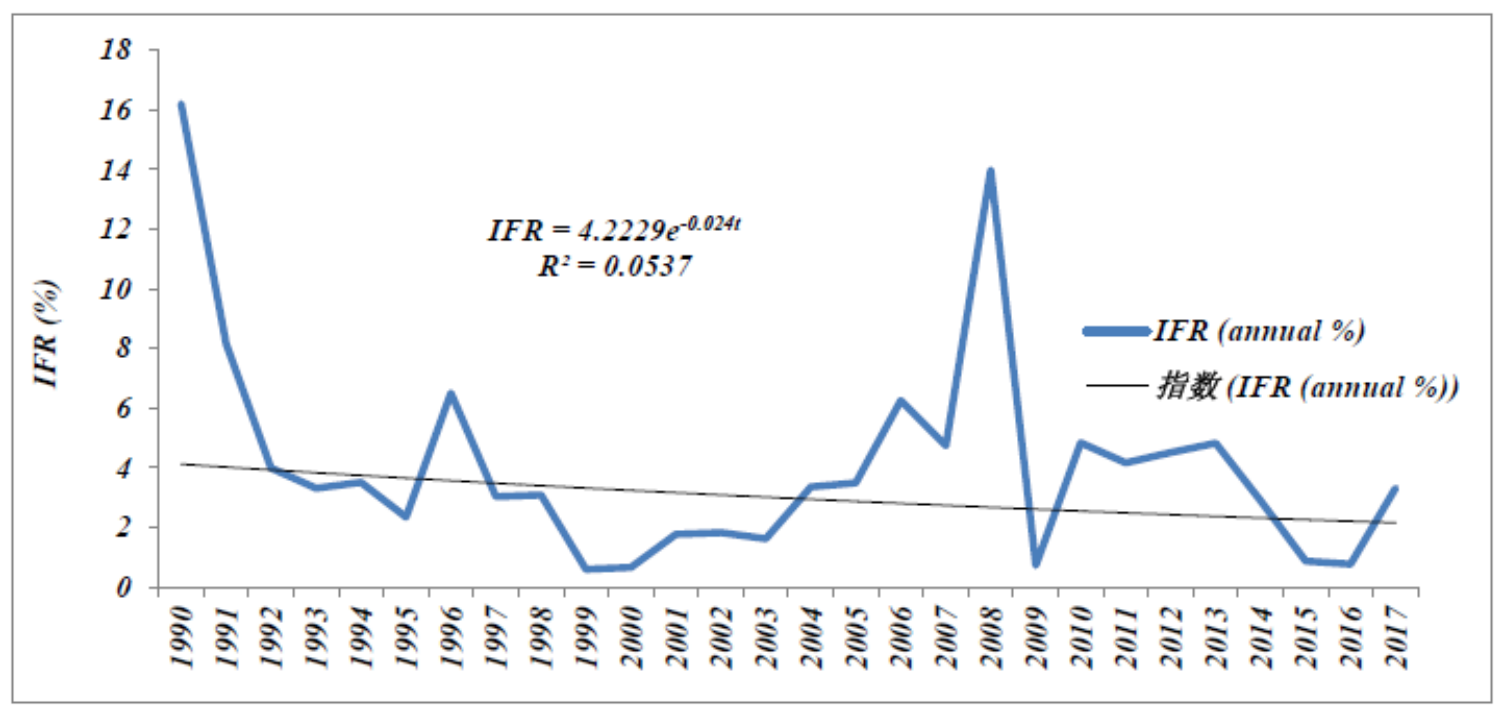

\section{Copyrights}

Copyright for this article is retained by the author(s), with first publication rights granted to the journal.

This is an open-access article distributed under the terms and conditions of the Creative Commons Attribution license (http://creativecommons.org/licenses/by/4.0/). 